$\begin{array}{lll}\text { War in Iraq } & \begin{array}{l}\text { Family trees } \\ \text { Aid agencies express } \\ \text { fears over conditions } \\ \text { in Basra }\end{array} \\ p 459 & \begin{array}{l}\text { Geneticists join the } \\ \text { hunt for human } \\ \text { ancestors } \\ p 460\end{array} & \begin{array}{l}\text { University faces legal } \\ \text { action over funding } \\ \text { for Biosphere 2 } \\ p 461\end{array}\end{array}$

\title{
Researchers rage at tightened restrictions on US immigration
}

Geoff Brumfiel, Washington

Scientific leaders are increasingly fearful that tighter immigration procedures, introduced in the wake of the terrorist attacks on 11 September 2001, are threatening the United States' position as a magnet for the world's scientific talent.

Researchers from countries as diverse as Indonesia and Germany are now subject to detailed security checks and rigorous interviews. The clampdown covers first-time visitors to the United States and those returning to lab positions there - delaying trips by weeks or months, and deterring some from coming at all.

The consequences of the change, which intensified with the introduction last August of new visa guidelines for consular officials, could be far-reaching. "We are in a rapid transition, whereby the United States will cease to be the destination of choice for researchers," predicts Irving Lerch, director of international affairs at the American Physical Society.

Some researchers and officials outside the United States - such as those at top European universities - acknowledge that they could benefit from a protracted reduction in the flow of scientists into US institutions. But publicly, at least, they draw little comfort from the situation.

"I'd prefer a world in which individuals make free decisions about where to go and

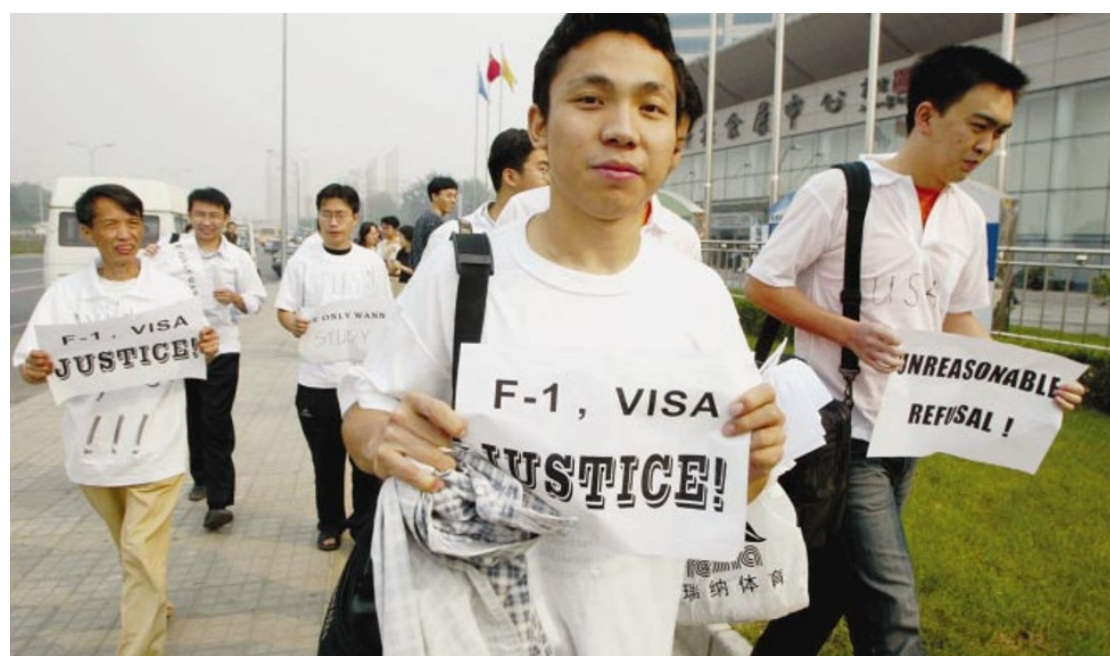

Locked out: Chinese students protest over the US embassy's refusal to grant them a study visa.

work," says Robert May, president of Britain's Royal Society. "We need to keep Britain and other European destinations attractive for scientists - but not as secondchoice countries."

Last week in Congress, the House Science Committee held hearings to address scientists' concerns. "The current situation is untenable," argued the committee's chairman, Sherwood Boehlert (Republican, New York). "Foreign students fill our graduate programmes; foreign scholars fill our faculty and laboratory positions. These people are a vital source of new ideas and perspectives." But not all committee members agreed, with some voicing satisfaction at the exclusion of foreign scientists (see below).

The overall scale of the shift is difficult to quantify, but some indicators suggest that it is significant. At the Human Frontier Science Program, which funds international collaborations between biologists, for example, the

\section{Congressmen unmoved by foreigners' plight}

Worries about the entry delays being experienced by foreign researchers coming to the United States were the avowed topic of a hearing of the House Science Committee on 26 March. But most of the members who turned up had different concerns on their minds. They wanted to know what is being done to make the United States more secure - and to lessen its dependency on foreign scientific talent.

"I am not particularly concerned that there is a little bit more red tape," Phil Gingrey (Republican, Georgia) told the scientific leaders who testified at the hearing. "Our security is more important than your convenience."

Ralph Hall (Democrat, Texas), the senior minority member on the committee, said that America's dependence on foreign students bothered him almost as much as the country's dependence on foreign oil.

And Dana Rohrabacher (Republican, California) suggested that the domestic shortage could be remedied if US students were given preference over foreigners for places in US graduate education programmes. "There are scientists from communist China swarming all over Los Alamos lab," he said, "and when the Chinese start building rockets efficiently enough to hit any American city, we can start blaming this open exchange that we've had between scientists and our universities."
Some research leaders at the hearing were discouraged by the lack of sympathy expressed by committee members towards the plight of foreign scientists. But Wendy White, who directs the National Academies' Board on International Scientific Organizations, was pleased just to see the issue raised. "I was heartened by the fact that there were hearings at all," she says.

Hall and Sherwood Boehlert (Republican, New York), the chairman of the committee, said at the hearing that they have written to the General Accounting Office requesting a study to assess the backlog and to review visa security-check procedures. 
percentage of fellowship applicants who want to work in the United States has fallen from $75 \%$ in 2001 to $55 \%$ this year.

"The arbitrariness of the US immigration machinery has increased to a disturbing degree," laments Erwin Neher, director of the Max Planck Institute of Biophysical Chemistry in Göttingen, Germany, who won the 1991 Nobel Prize in Medicine for his work on ion channels in cells. Several foreign scientists at the institute - from countries such as South Korea, India and Hungary — and at the nearby European Neuroscience Institute have been refused US visas altogether, Neher claims. "It is awful", he says. "Our PhD student exchange programme with Stanford University is suffering badly."

US research programmes, such as that of the Center for Nonproliferation Studies in Monterey Bay, California, are also feeling the pinch. Several researchers from the countries that the centre needs to work with, including China and parts of the former Soviet Union, have been denied entry to the United States. "I'm supportive of greater controls, but they are using a veryblunt instrument and they are weeding out the wrong people," argues Clay Moltz, a project director at the centre. Before 11 September 2001, Moltz says, he could usually talk to the US embassy in the country concerned to move an application along. Now the embassies don't return his calls. "There is no communication at all. You file these things and wait," he says.

Also affected are public-health programmes, particularly those aimed at tackling infectious diseases such as HIV. Chris Beyrer, who directs the AIDS International Training and Research Program at Johns Hopkins University in Baltimore, Maryland, says that visa delays have occurred in all of the dozen or so countries with which his programme deals. Practically every applicant from China, where HIV is rapidly taking hold, has encountered long delays, he says. US embassies in Uganda and Thailand are entirely rejecting visa applications from about 1 in 10 of those seeking training at Johns Hopkins, Beyrer says. "We need to train scientists in Africa, and some of them have to get to the States," he says. "Antiviral therapy for AIDS is not something you can learn from a handout."

Visitors to the United States have faced tighter entry controls ever since the 2001 terrorist attacks, but the problems intensified last August, when the Department of State broadened its guidelines covering visiting researchers from "sensitive countries" to encompass those from all destinations. Under the guidelines, candidates for work and study visas whose applications mention any of a wide range of topics - including chemical engineering, biochemistry and microbiology — face possible interviews by consular officials (see above right).

After these interviews, officials can elect to

\section{Physicist discouraged by heightened security}

When Wolfgang Caliebe tried to return to work at the Brookhaven National Laboratory in New York state after a Christmas break at home in Germany, he was surprised to find himself subjected to a security review.

In previous years, Caliebe - a native of Kiel who has spent ten years as a student and researcher in the United States - has never had to wait more than a week or so for his visa to be renewed. But this time, when he applied for its extension, he was told he would have to stay in Germany for at least a month and be interviewed by an officer at the US consulate in Frankfurt. He eventually got back to Brookhaven, but says that he has now given up on a career in the United States and is searching for a job back home.

Caliebe is one of a handful of physicists who provide technical support at the National Synchrotron Light Source, a facility used by some 2,500 scientists to image molecular structures and materials. "If one of us is gone, we are very thinly spread," he says. Furthermore, Caliebe is the only one dedicated to caring for an elasticscattering instrument at the source. "If they have a problem and I'm not around, the instrument just sits around and collects dust," he adds.

With the help of Brookhaven officials, Caliebe was able to lobby for an earlier date for his interview that would delay his return by just two weeks. But in the days before the meeting, he was very much on edge. "I didn't know why they had invited me for an interview," he says.

"Sometimes, I couldn't sleep at night."

When the time came, Caliebe was confronted by an officer who asked a series of questions about his work. "I described how the storage ring works, but she didn't understand that," he says. He says that the officer's attention only picked up when he mentioned radiation. "I was scared at that point," he recalls. "I felt worse than I did during my $\mathrm{PhD}$ defence."

In the end, Caliebe got his visa, but he says that colleagues at Brookhaven have fared less well. One student from Indonesia had to wait three months to return to the United States. "Now he has to go regularly to the police station and tell

send the application to Washington DC for an interagency security review. Hundreds of scientific applications have been referred for such reviews, partly because consular officials lack scientific training. And with several agencies - including the Federal Bureau of Investigation, Central Intelligence Agency, Department of Homeland Security and Department of Defense - having to check each case, this process can take months.

"I'm aware of the problems, and I think they are serious," says John Marburger, President George W. Bush's science adviser. Marburger says that his staff at the White House Office of Science and Technology Policy is meeting "almost every day" with

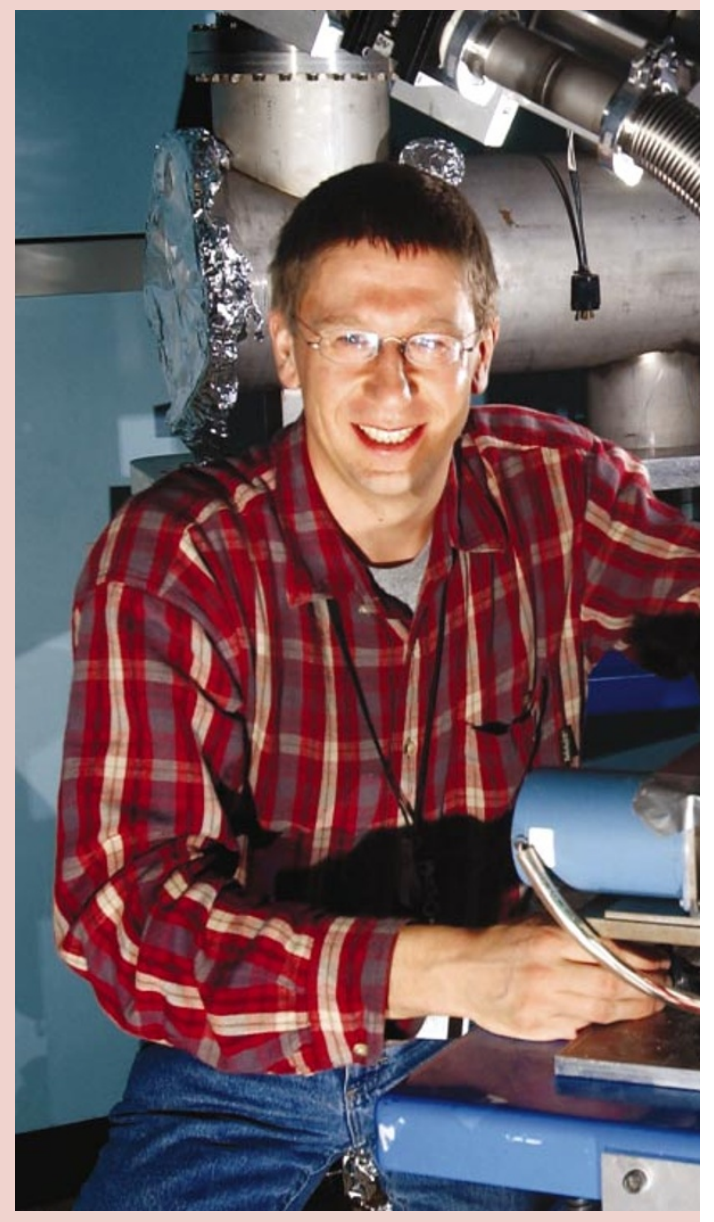

Wolfgang Caliebe: questioned before his return.

them, 'Yes, I still work at Brookhaven, and I'm a nice guy'," Caliebe says.

Caliebe's experience has persuaded at least one German graduate student, who sought advice from him on postdoctoral openings, to steer clear of the United States. "I described to him the situation I was just in, and he said: 'OK then, l'd better look in Europe',"

Caliebe says.

Geoff Brumfiel

agencies throughout the government to speed up the visa process. Marburger hopes to streamline the reviews, and to involve more scientifically qualified people in them. "I think we can do a better job without increasing the risk of terrorism," he says.

But most observers don't expect the situation to improve any time soon. The United States' top priority is national security, points out one official in the Department of Energy, who works with visa applications. "No one wants someone to point a finger at them and say 'You just caused the death of 3,000 Americans," the official says.

Additional reporting by Quirin Schiermeier in Munich and Jonathan Knight in San Francisco. 